\title{
AKAR PEMIKIRAN REALISME DALAM HUKUM ISLAM
}

\author{
Anwar Sofiyudin Yusuf \\ Universitas Islam Negeri Syarif Hidayatullah \\ E-Mail: anwarsyusuf@yahoo.com
}

\begin{abstract}
Talking about realism in Islamic law, it is still a very interesting to be studied, especially if it confronted to the characteristic of idealism in Islamic law. As if they become two magnetic poles which will never be united, realism can be a threat to the ideals of Islamic law itself. In the idealism view, reality must be subject to the law, but in realism view, it is the opposite, it mean that the law should follow reality. However, it is not important whether the law follows the reality or otherwise. The faithful law should follow reality. Because in the end, the legal system is needed to be resolved in every case that occurs in the community. Sosial reality in fact be an important entity in influencing the formation of Islamic law, in the form of fatwas of scholars, Judges decision or the books of fiqh, and not least the Quran and Hadith.
\end{abstract}

\begin{abstract}
Abstrak
Membicarakan realisme dalam hukum Islam, masih menjadi kajian yang tak kunjung basi terlebih realisme dihadap-hadapkan pada karakter idealisme hukum Islam. Seolah menjadi dua kutub magnet yang tidak pernah akan bisa bersatu, realisme kerap menjadi ancaman bagi idealisme hukum Islam itu sendiri. Jika dalam pandangan idealisme realitas harus tunduk pada hukum, maka dalam pandangan realisme sebaliknya, hukumlah yang harus mengikuti realitas. Namun, tidaklah penting apakah hukum yang mengatur realitas atau sebaliknya, hukum yang setia mengikuti realitas. Sebab pada akhirnya, sistem hukum dibutuhkan untuk menyelesaikan setiap kasus yang terjadi di masyarakat. Realitas sosial nyatanya menjadi entitas penting dalam mempengaruhi proses pembentukan hukum Islam, baik berupa fatwa-fatwa ulama, keputusan hakim maupun kitab-kitab fiqih, tak terkecuali Al-Quran dan Hadits.
\end{abstract}

Kata Kunci:

Realisme, Idealisme, Hukum Islam

\section{A. Pendahuluan}

Dalam memahami hukum Islam, ada dua hal yang harus dijadikan pertimbangan. Pertama, hukum Islam sebagai hukum yang diyakini bersumber dari Tuhan. Dalam dimensi ini, hukum Islam diyakini oleh umat Islam sebagai ajaran suci karena bersumber dari dzat Yang Maha Suci, Maha Sempurna dan Maha Benar. Kedua, hukum Islam sebagai hukum yang diyakini dalam proses pembentukannya tidak lepas dari campur tangan manusia. Dalam dimensi ini hukum Islam dipahami sebagai produk pemikiran yang dilakukan dengan berbagai pendekatan yang dikenal dengan sebutan ijtihad atau pada tingkat yang lebih teknis disebut istinbâth al-ahkâm. ${ }^{1}$

Sedikitnya ada empat macam produk pemikiran hukum Islam yang kita kenal dalam perjalanan sejarah Islam, yaitu: kitab-kitab figh, fatwa-fatwa ulama, keputusan-keputusan

1Juhaya S. Praja, "Kata pengantar" dalam Dedi Supriyadi, Sejarah Hukum Islam: Dari Kawasan Jazirah Arab sampai Indonesia (Bandung: Pustaka Setia. 2007), cet. ke1, hlm. 5-6. 
pengadilan agama, dan peraturan perundangundangan di negeri-negeri Muslim. ${ }^{2}$ Keempat produk pemikiran hukum Islam ini merupakan fakta yang tidak terbantahkan yang mewakili gambaran realisme dalam hukum Islam.

Konsekwensi dari pandangan di atas adalah terjadinya sebuah antinomi yang cukup menegangkan, yaitu idealisme dan realisme dalam hukum Islam. Meski terlihat berbeda bahkan bertentangan, namun jika dicermati akan dapat dipahami bahwa masing-masing secara simbolis saling berhubungan dan bersifat komplementer, dan bukan saling bertentangan. ${ }^{3}$

Tulisan ini dibuat tidak dalam kerangka meredakan ketegangan dua kutub tersebut apalagi mempertemukannya, tapi lebih kepada analisis deskriptif untuk mencari akar genealogis munculnya tesis-tesis realisme dalam hukum Islam yang dalam kajian penulis jejaknya tidak hanya ditemukan pada konteks historis-sosiologis (ijtihad para ulama) tetapi juga historis-teologis (wahyu).

\section{B. Karakteristik Hukum Islam}

Dalam pemikiran hukum Islam terdapat perbedaan antara syari'ah dan fiqih. Syari'ah berarti "jalan ke sumber air". Orang-orang Arab menggunakan istilah ini dalam pengertian jalan setapak menuju sumber air yang tetap dan diberi petunjuk yang jelas sehingga nampak oleh mata. ${ }^{4}$ Dalam al-Quran, syari'ah menunjukkan suatu ketentuan dari Allah untuk diikuti dengan tidak mengikuti hawa nafsu. ${ }^{5}$

Di kalangan para ulama, syari'ah dipahami sebagai hukum-hukum yang ditetapkan oleh

${ }^{2}$ M. Atho' Muzdhar, "Fiqih dan Reaktualisasi Ajaran Islam" dalam Budhy Munawar-Rachman (ed.) Kontekstualisasi Doktrin Islam dalam Sejarah (Jakarta: Paramadina. 1995), cet. ke-5, hlm. 369.

${ }^{3}$ Imam Syaukani, Rekonstruksi Epistemologi Hukum Islam Indonesia (Jakarta: PT. RajaGrafindo Persada. 2006), hlm. 166.

${ }^{4}$ Abu Fazal Jamaluddin, Lisan al-Arab, jilid III, h. 19751976. Dikutip dari Ghufran A. Mas'adi, Pemikiran Fazlur Rahman tentang Metodologi Pembaruan Hukum Islam, (Jakarta: Rajawali Press. 1997), hlm. 81.

${ }^{5}$ QS. Al-Jatsiyah: 18.
Allah untuk hamba-hambanya yang dibawa oleh Nabi SAW. berupa aturan berakidah dan bertingkah laku. ${ }^{6}$

Sedangkan fiqih berarti "mengetahui, memahami sesuatu". Dalam al-Quran istilah ini digunakan dalam pengertian memahami secara umum, seperti dalam ungkapannya "liyatafaqqahû fî al-dîn". Menurut pengertian istilahi, fiqih berarti menyimpulkan hukum dari dalildalil syari'ah.?

Dalam konsep hukum Islam, terdapat perbedaan yang tipikal antara syari'ah dan fiqih, sebagaimana diungkapkan oleh Yusuf Musa, ${ }^{8}$ antara lain :

1. Perbedaan ruang lingkupnya: syari'ah lebih luas cakupannya meliputi seluruh ajaran agama, sedangkan fiqih hanya mencakup hukum-hukum perbuatan manusia.

2. Perbedaan dalam hal subyek: syari'ah berasal dari Tuhan, sedangkan fiqih berasal dari (ijtihad) manusia.

3. Perbedaan mengenai asal mula digunakannya dalam istilah teknis: syari'ah digunakan semenjak awal sejarah Islam, sedangkan fiqih mulai digunakan setelah lahirnya ilmu-ilmu ke-Islaman pada abad ke2 Hijriyah.

Perbedaan ini penting diungkapkan untuk menjelaskan karakteristik hukum Islam dalam pengertian syari'ah.

Syari'ah tidak lain merupakan pernyataan sifat Tuhan dan usaha untuk menegakkan perdamaian dan keadilan bagi manusia di dunia. Atas dasar ini Muhammad Muslehuddin menyebut beberapa karakteristik yang dimiliki hukum Islam, antara lain:

1. Hukum Islam adalah hukum yang ideal (sempurna). Hal ini disandarkan pada sifat Maha Meliputi yang melekat pada pembuat hukum (Allah). Allah adalah Maha

\footnotetext{
${ }^{6}$ H.A. Djazuli, Ilmu Fiqih (Bandung: Orba Shakti. 1993), cet. ke-4, hlm. 13-14.

${ }^{7}$ Ibid. hlm. 16.

${ }^{8}$ Ghufran A. Mas'adi, Pemikiran Fazlur Rahman tentang Metodologi Pembaruan Hukum Islam (Jakarta: Rajawali Press. 1997), hlm. 83.
} 
Sempurna, dengan demikian hukum-Nya bisa dipastikan sempurna juga. Dengan demikian hukum Islam itu universal. ${ }^{9}$

Hukum Islam merupakan serangkaian aturan hukum-hukum yang harus ditaati oleh manusia. Idealisme hukum Islam juga berarti bahwa segala keputusan hukum berada di tangan Allah semata, dan hukum Allah dijadikan sebagai timbangan satu-satunya. ${ }^{10}$

2. Hukum Islam berasal dari dzat yang memiliki kedaulatan bagi seluruh alam dan manusia. Kedaulatan Tuhan meliputi sifatnya sebagai Penguasa, Pelindung, Pemberi harapan, Pemberi rizki, Pengatur dan Penyempurna. Dialah Pencipta dan Pengatur seluruh alam ini, sehingga yang berlaku adalah hukum-Nya serta tidak ada yang berhak dan dapat merubahnya." Inilah karakter kemutlakan (absolutisme) hukum Islam.

3. Hukum Islam adalah hukum yang abadi, berlaku dan akan senantiasa sesuai dengan segala tempat dan waktu, sebab ia berasal dari dzat yang Maha Abadi. Hal ini menjadi kemestian, selain karena berasal dari Tuhan, juga untuk menjaga susunan sosial Islam yang teratur dan terjamin sepanjang masa. ${ }^{12}$

Karakter idealisme, absolutisme dan keabadian hukum Islam merupakan implikasi dari postulasi bahwa hukum Islam berasal dari Allah. Namun, hal yang tidak bisa diabaikan dari karakteristik hukum Islam adalah bahwa syari'ah berisikan prinsip-prinsip umum yang dimaksudkan untuk dipahami sebagai suatu etika Islam dan karenanya, dapat memunculkan berbagai interpretasi. Di sinilah kita bisa meletakkan syari'ah sebagai sebuah "tekstur terbuka", sebuah struktur norma yang tertulis

\footnotetext{
${ }^{9}$ Muhammad Muslehuddin, Filsafat Hukum Islam dan Pemikiran Orientalis, terj. Yudian W. Asmin (Yogyakarta: Tiara Wacana. 1997), cet. ke-2, hlm. 47.

${ }^{10}$ lbid. hlm. 94-95.

${ }^{11}$ Ibid. hlm. 45-46.

${ }^{12}$ Ibid. hlm. 67-68.
}

secara baku, yang terbuka terhadap interpretasi. ${ }^{13}$

Kesempurnaan, kemutlakan dan keabadian hukum di satu sisi, dan jaminan keberlakuan sepanjang masa serta tuntutan kebutuhan manusia yang terus berkembang di sisi lain, menjadikan hukum Islam mengandung antinomi-antinomi yang harus didamaikan satu sama lainnya. Antinomi tersebut adalah wahyu dan akal, kesatuan dan keragaman, idealisme dan realisme, stabilitas dan perubahan. ${ }^{14}$

Doktrin agama yang menyatakan bahwa agama Islam telah sempurna ${ }^{15}$, namun kesempurnaan hukumnya masih dalam batasan-batasan yang umum. Pada kesempatan tertentu, riwayat yang mengisahkan dialog Rasulullah dengan Muadz bin Jabal tentang ijtihad, menandakan bahwa kesempurnaan hukum Islam tidak menegaskan adanya kewajiban ijtihad dalam Islam. Kenyataan ini menunjukkan bahwa penalaran (rasio) merupakan sumber hukum kedua setelah wahyu.

\section{Akar Pemikiran Realisme dalam Hukum Islam}

Menurut Kamus Besar Bahasa Indonesia, realisme berasal dari bahasa Inggris "real" berarti "nyata". Realisme berarti ajaran yang selalu bertolak dari kenyataan. Dalam bidang kesenian, realisme dikenal sebagai aliran yang berupaya melukiskan sesuatu sebagaimana kenyataannya. ${ }^{16}$

Dalam filsafat hukum, memang tidak dikenal ada aliran realisme, namun jika realisme merupakan lawan dari idealisme, maka sesungguhnya positivisme, terutama positivism pragmatis sebagai sebuah aliran filsafat hukum

\footnotetext{
${ }^{13}$ Konsep hukum sebagai sebuah "tekstur terbuka" pertama kali diperkenalkan oleh H.L.A. Hart dalam bukunya The Concept of Law. Lihat Bassam Tibi, Islam Kebudayaan dan Perubahan Sosial, terj. Misbah ZE dan Zainul Abbas (Yogyakarta: Tiara Wacana. 1999), hlm. 112.

${ }^{14}$ Muhammad Muslehuddin, Filsafat Hukum. hlm. 90.

${ }^{15}$ QS. Al-An'am: 3

${ }^{16}$ Tim Penyusun Kamus P3B, Kamus Besar Bahasa Indonesia (Jakarta: Balai Pustaka. 1995), cet. ke-4, hlm. 823.
} 
yang muncul dari kalangan realis, memiliki kesamaan dengan realisme.

Dalam doktrin positivisme-pragmatis, terdapat mainstream pemikiran hukum yang mengatakan bahwa fakta sosial merupakan unsur yang menentukan konsep hukum. Hukum dengan demikian selalu tunduk pada kenyataan yang terjadi di masyarakat sebagai fakta sosial. Hukum juga selalu mengalami perubahan seiring dengan terjadinya perubahan yang ada di masyarakat. ${ }^{17}$

Realisme dalam hukum Islam tidak berarti positivisme dimana hukum Islam ditentukan oleh fakta sosial yang terjadi di masyarakat, karena hukum Islam adalah hukum Tuhan. Realisme dalam kaitannya dengan hukum Islam berarti bahwa pemahaman hukum Islam didasarkan atas pertimbangan realitas sosial yang berkembang di masyarakat. Atau pada tingkat yang sangat teknis bagaimana keputusan-keputusan hukum diambil berdasarkan pada fakta-fakta yang terjadi di tengah-tengah masyarakat.

Hal ini berkaitan dengan konsep maqâshid as-syari'ah dalam metodologi hukum Islam, dimana sesungguhnya syari'ah itu dibuat untuk mewujudkan kemaslahatan manusia di dunia dan di akhirat. ${ }^{18}$ Kemaslahatan bahkan menjadi tujuan hakiki dari hukum Islam itu sendiri. ${ }^{19}$ Pandangan ini secara umum bertitik tolak dari kandungan ayat-ayat al-Quran yang menunjukkan bahwa hukum-hukum Tuhan mengandung kemaslahatan, seperti tertera dalam Q.S. AlNisâ: 165, al-Anbiyâ: 107, Hud: 7, al-Dzariyat: 56, al-Ankabut: 45, dan lain-lain. Berdasarkan ayatayat di atas, kemaslahatan terdapat dalam setiap aspek hukum secara keseluruhan. Hal ini mengandung pengertian, jika terdapat kasuskasus hukum yang tidak ditemukan dimensi kemaslahatannya, maka dapat dianalisis mela-

\footnotetext{
${ }^{17}$ Muhammad Muslehuddin, Filsafat Hukum. hlm. 94.

${ }^{18}$ As-Syatibi, Al-Muwâfaqât fī Ușhûl al-Syarî'ah (Kairo: Musthafa Muhammad, t.th.), jilid I, hlm. 6.

${ }^{19}$ Muhammad Abu Zahrah, Ușhûl al-Fiqh, (Mesir: Dâr al-Fikr al-Arabi. 1958), hlm. 366.
}

lui maqâshid as-syari'ah sebagai tujuan umum dari hukum Islam itu sendiri. ${ }^{20}$

Secara genealogis, semangat realisme dalam hukum Islam dapat ditelusuri jejaknya dari syari'ah atau wahyu Allah itu sendiri. Dalam disiplin ilmu-ilmu al-Quran ('ulûm al-Qur'ân), dikenal istilah asbâb al-nuzûl (sebab-sebab turunnya al-Quran) dan nasakh (pembatalan Nash). Dalam tradisi sunnah, dikenal istilah asbâb alwurûd (sebab-sebab datangnya Hadits). Sementara dalam tradisi sahabat dikenal dengan adanya ijtihad. ljtihad bahkan telah terjadi ketika Rasulullah masih hidup.

\section{Asbâb al-nuzûl}

Asbâb al-nuzûl adalah konsep, teori atau berita tentang adanya sebab-sebab turunnya wahyu tertentu dari al-Quran kepada Nabi SAW. baik berupa satu ayat, satu rangkaian ayat atau satu surat. ${ }^{21}$ Dalam pemahaman tradisional, asbâb al-nuzûl berkaitan dengan periwayatan sebab turunnya wahyu atau ayat, waktu, tempat, serta situasi pewahyuan itu. Ringkasnya asbâb al-nuzûl merupakan kejadian yang menyebabkan turunnya wahyu. ${ }^{22}$

Dalam teori asbâb al-nuzûl terdapat istilah "generalitas lafadz" dan "partikularitas sebab". Dalam upayanya mengeluarkan sebuah hukum, terdapat dua pertentangan mana yang harus dijadikan sebagai pegangan, generalitas lafadz atau partikularitas sebab. Sebagian besar para ahli hukum Islam lebih banyak berpatokan pada generalitas lafadz, yang kaidahnya berbunyi "Pengambilan makna didasarkan pada generalitas lafadz, bukan pada partikularitas sebab" (al-ibrah bi umûm al-lafdz, lâ bi khusûs al-sabâb).

Akan tetapi, sebuah generalisasi akan sulit dilakukan tanpa mengetahui inti pesan yang

\footnotetext{
${ }^{20}$ Asafri Jaya Bakri, Konsep Maqâshid Syari'ah Menurut Al-Syatibi (Jakarta: PT RajaGrafindo Persada. 1996), cet. ke-1, hlm. 68.

${ }^{21}$ Nurcholish Madjid, “Konsep Asbâb al-Nuzûl: Relevansinya Bagi Pandangan Historisis segi-segi Tertentu Ajaran Keagamaan" dalam Budhy Munawar-Rachman, Kontekstualisasi Doktrin. hlm. 24.

${ }^{22}$ Farid Esack, Al-Quran Liberalisme dan Pluralisme: Membebaskan Yang Tertindas, terj. Watung A. Budiman (Bandung: Mizan, 2000), h. 88-89.
} 
ada dalam sebuah firman Tuhan, sehingga sangat ditentukan oleh kemampuan memahaminya. ${ }^{23}$ Imam Syafi'i sendiri berpendapat bahwa generalitas lafadz tidak selalu dapat dijadikan dalil untuk menggeneralisasi, sebab ada lafadz yang umum, namun maksudnya khusus, sehingga sebenarnya persoalan umum dan khusus adalah persoalan bahasa. Atas dasar ini, yang mesti menjadi norma adalah "teks" itu sendiri dengan perangkat yang membentuk teks, yakni asbâb al-nuzûl. ${ }^{24}$

Asbâb al-nuzûl dapat dilihat dalam kaitannya dengan dialektika antara teks dan realitas, sehingga asbâb al-nuzûl dipahami sebagai fakta-fakta sejarah yang menyelimuti pembentukan teks. ${ }^{25}$ Dalam pengertian ini, asbâb al-nuzûl menunjukkan bahwa wahyu tidaklah menentukan realitas, tetapi justru diundang oleh realitas aktual itu sendiri. ${ }^{26}$ Asumsi inilah yang menunjukkan bahwa eksistensi realitas memiliki peran penting bagi pembentukan sebuah teks. Dengan kata lain, dimensi realisme berasal dari dalam teks itu sendiri.

\section{Nasakh}

Secara bahasa nasakh memiliki beberapa arti; 'izâlah (penghilangan), tabdîl (pergantian), tahwîl (pengalihan), atau naql (pemindahan $)^{27}$. Secara terminologis, nasakh memiliki sedikitnya 2 pengertian; Pertama, nasakh adalah penjelasan berakhirnya masa berlakunya suatu hukum melalui dalil syara' yang kemudian datang. Kedua, pembatalan hukum syara' yang telah ditetapkan terdahulu dengan dalil syara‘ yang datang kemudian.

\footnotetext{
${ }^{23}$ Nurcholish Madjid, Konsep Asbab. hlm. 30.

${ }^{24}$ Nasr Hamid Abu Zaid, Tekstualitas Al-Quran: Kritik Terhadap 'Ulûmul Qur'an, terj. Khoiron Nahdliyin (Yogyakarta: LKiS. 2001), hlm. 140.

${ }^{25}$ Farid Esack, Al-Qur'an Liberalisme; Bandingkan dengan Ibid. hlm. 126-133.

${ }^{26}$ Hassan Hanafi, "Maza Ta'ni Asbâb al-Nuzûl” dalam al-Din wa as-Saurah fi Misr 1956-1981 (Cairo: Maktabah Madbuli. 1981), vol. VII, hlm. 71.

${ }^{27} \mathrm{Nn}$. Lebih Dekat Mengenal Ilmu Nasakh dan Mansukh, lihat di http://www.bimbie.com/nasikh-danmansukh.htm di akses pada tanggal 19 Agustus 2014 pukul 13:50 WIB.
}

Konsep nasakh memiliki keterkaitan yang sangat erat dengan asbâb al-nuzûl. Asumsi ini didasarkan pada pandangan bahwa, kalau asbâb al-nuzûl dianggap sebagai realitas, dan realitas itu selalu berkembang, maka pada proses selanjutnya memungkinkan terjadinya perubahan atau pergantian teks karena terjadinya perubahan realitas. Dalam konteks ini, "pergantian" teks ayat berarti perubahan hukum yang ada pada satu teks dengan teks lain dengan tetap mempertahankan kedua teks tersebut. ${ }^{28}$

Selain dipahami memiliki fungsi gradualisasi dari penerapan syari'ah, nasakh berarti menunjukkan historisitas wahyu, keterlibatan wahyu dengan sejarah. Pada gilirannya, seperti kata Hassan Hanafi, wahyu tidaklah muncul di luar realitas. ${ }^{29}$

Beberapa pemahaman baru terhadap konsep-konsep di atas merupakan langkah awal yang harus dilalui dalam menafsirkan alQuran dan sunnah untuk merumuskan kembali realitas yang dihadapi kaum muslimin dewasa ini. Dari sinilah kemudian ditarik benang merah untuk mencocokkan realitas ketika teks itu muncul dengan realitas kaum muslimin dewasa ini. Kedua realitas yang berbeda tersebut kemudian dipertemukan melalui prinsip kemaslahatan manusia yang menjadi tujuan primer seluruh legislasi syari'ah. ${ }^{30}$

\section{3. ljtihad}

ljtihad secara etimologis berarti mengerahkan tenaga dan kemampuan atau menanggung dan memikul kesulitan. ${ }^{31}$ Sedangkan secara terminologi, ijtihad di kalangan ushuliyyun (ahli ilmu ushûl figh) adalah mencurahkan se-

\footnotetext{
${ }^{28}$ Nasr Hamid Abu Zaid, Tekstualitas Al-Quran. hlm. 154.

${ }^{29}$ Hassan Hanafi, Dirâsat Islamiyyah (Kairo: Maktabah Anjilu Misriyyah, t.th.), hlm. 29-31.

${ }^{30} \mathrm{Abu}$ Ishaq Ibrahim asy-Syatibi, Al-Muwafaqat $\mathrm{fi}$ Ushûl al-Ahkam (Bairut: Dâr al-Fikr, t.th.), Jilid II, hlm. 2-3.

${ }^{31}$ Rauf Muhammad Amin, Dialektika ljtihad dan Realita Kajian Metodologis Aktualisasi Hukum Islam Kontemporer, lihat di http://saidnazulfiqar.wordpress.com/2005/04/02/dialektika-ijtihad-dan-realita/ diakses pada tanggal 15 Agustus 2014 pukul 17:13 WIB.
} 
gala kemampuan oleh seorang mujtahid untuk mencari pengetahuan tentang hukum-hukum syara'. ${ }^{32}$

Imam Al-Syatibi memberikan warna lain terkait definisi ijtihad. Menurutnya, ijtihad dibedakan kepada 2 macam: Pertama, ljtihad memiliki pengertian mengerahkan kemampuan untuk menentukan subtansi obyek (manath) hukum setelah status hukumnya sendiri sudah diperoleh dari dalilnya yang sah. Istilah ini populer dengan sebutan "tahqiq al-manat". Kedua, ijtihad dipahami sebagai menginventarisasi beberapa hal yang mungkin menjadi kata kunci atau logika (illat) suatu ketetapan hukum, atau dalam istilah populernya "tanqiq almanat."

Dari gambaran definisi di atas, ijtihad yang sangat urgen adalah tipe ijtihad dinamis, yang memusatkan perhatiannya pada manusia, kasus atau realitas sebagai obyek hukum bukan pada teks sebagai subyek/sumber hukum. Pada intinya institusi ljtihad memiliki hubungan aktif-pasif dengan realitas sosial. ljtihad mesti mempengaruhi dan pada saat yang sama harus dipengaruhi oleh realitas sosial yang ada. ${ }^{33}$

Sejarah panjang dialektika ijtihad dengan realitas sosial telah terjadi bahkan semenjak Rasulullah masih hidup. Kasus yang paling kuat indikasinya adalah model penerapan sangsi bagi seorang Arab Badui terkait pelanggaran puasa. Dalam kasus ini terjadi sekitar lima kali perubahan hukum sesuai perubahan realitas Arab badui yang meminta fatwa dari Nabi. Proses tawar-menawar hukuman antara Nabi dengan Arab badui ini terjadi karena terjadinya perubahan realitas yang dihadapi Arab badui sehingga menyebabkan terjadinya perubahan hukum itu sendiri. Kasus ini juga mengisyaratkan bagaimana kepiawaian Nabi dalam merukunkan realitas sosial dengan idealitas agama, betapa Nabi sangat mempertimbangkan ma-

\footnotetext{
${ }^{32}$ Abu Hamid Al-Ghazali, Al-Mustasfa min 'Ilm alUshûl (Beirut: Dâr al-Fikr, t.th.), Jilid II, hlm. 489.

${ }^{33}$ S Samsidar, Signifikasi Maqâshid asy-Syari'ah, lihat di download.portalgaruda.org/article.php?...Syatibi\%20T... diakses pada tanggal 19 Agustus 2014 pukul 13.55 WIB
}

nusia sebagai sentral dibanding Nash sebagai prioritas.

Sepeninggal Nabi, ljtihad Umar bin Khaththab tentang hukuman bagi pelaku pencurian selanjutnya menjadi pilihan tepat untuk dikemukakan dalam konteks pendalaman pemahaman terhadap realitas. Meski terlihat bersebrangan dengan Nash, Umar bukan tanpa alasan melakukan perubahan hukum demi menjembatani kesenjangan antara idealitas hukum dengan realitas sosial. Tujuannya tiada lain adalah pertimbangan kemaslahatan manusia.

Gagasan kemaslahatan (maslahah) juga sudah mulai terumuskan dalam bangunan teori hukum Islam Imam Mâlik yang dilanjutkan oleh Imam Al-Ghazalî, meski penyempurnaannya berada di tangan Imam Al-Syathibi. Benang merah pemikiran ketiga tokoh berbeda zaman ini menegaskan bahwa kemaslahatan manusia menjadi

Imam al-Qarafi (626-684 H) salah seorang ahli hukum dari mazhab Mâliki berkata: "Pertimbangkanlah tradisi ("urf) yang masih berlaku dalam suatu masyarakat, dan janganlah melirik pada tradisi yang sudah tidak berlaku. Janganlah membelenggu diri pada karangan dan karya-karya ulama terdahulu seumur hidupmu. Jikalau datang seseorang kepadamu meminta fatwa dari daerah lain bukan daerah dimana kamu hidup, janganlah memperlakukannya seperti orang yang berasal dari daerahmu tapi tanyakanlah tradisi daerahnya lalu beri fatwa berdasarkan tradisi itu, bukan berdasarkan apa yang tertulis di dalam buku. Itulah kebenaran yang jelas, dan kemutlakan memberi fatwa berdasarkan apa yang tertulis dalam buku-buku adalah kesesatan dalam agama, dan itu berarti tidak memahami maksud para ulama islam dan ulama salaf terdahulu." 34

Berikutnya, dalam formulasi ijtihadnya, Imam Mâlik memberikan syarat-syarat bagi seorang mufti (pemberi fatwa) di antaranya; (1)

${ }^{34}$ Syihabudin Ahmad bin Idris al-Qarafi, Anwar alBuruq fi Anwa' al-furûq (Kairo: Dâr al-Fikr. t.th.), vol. I, hlm. 314. 
ia harus memiliki pendirian yang kuat (niat). (2) la mesti memiliki ilmu, ketenangan dan akhlak. (3) la kuat hati dalam mempertahankan posisinya dan ilmu pengetahuannya. (4) la harus mempunyai kehidupan yang cukup. (5) la harus memiliki pengetahuan yang memadai tentang manusia. ${ }^{35}$ Khusus pada point kelima, menegaskan bahwa realitas kemanusian menjadi faktor yang tidak diabaikan dalam proses pembentukan hukum Islam.

\section{Penutup}

Realisme hukum Islam merupakan sebuah pandangan bahwa dalam proses pembentukan hukum Islam baik dalam konteks figh maupun syari'ah realitas sosial menjadi faktor yang tidak bisa diabaikan. Secara genealogis, akar semangat realisme ini dapat digali dari konsepkonsep normatif yang tidak hanya ditemukan dalam kitab-kitab figh atau fatwa-fatwa mujtahid, lebih dari itu, juga terdapat dalam Al-Quran dan Hadits.

Semangat realisme hukum Islam menjadi penting dalam kerangka menjembatani kesenjangan yang terjadi dalam proses pembentukan hukum yang dapat menjawab problematika sosial. Sehingga, akan nampak hubungan yang sinergis antara idealisme hukum Islam dan realitas sosial yang ada.

Wallahu'alam bish-shawab.

\section{Daftar Pustaka}

Abu Zahrah, Muhammad. t.th. Ushûl al-Fiqh. Mesir: Dâr al-Fikr al-Arabi. - t.th. Al-Muwâfaqāt fĩ Ushûl alSyarīah. Kairo: Musthafa Muhammad.

Abu Zaid, Nasr Hamid. 2001. Tekstualitas AlQuran: Kritik Terhadap 'Ulumul Qur'an. terj. Khoiron Nahdliyin. Yogyakarta: LKiS.

Al-Ghazalî, Abu Hamid. t.th. Al-Mustasfa min 'Ilm al- Ushûl. Beirut: Dar al-Fikr.

\footnotetext{
${ }^{35}$ Ibn Qayyim al-Jauziyah, l'ilâm al-Muwâqiînn (Kairo: Dâr al-Fikr. t.th.), vol. IV, hlm. 199.
}

Al-Jauziyah, Ibn Qayyim. t.th. I'ilâm al-Muwâqi'în. Kairo: Dâr al-Fikr.

Al-Qarafi, Syihabudin Ahmad bin Idris. t.th. Anwar al-Buruq fi Anwa' al-Furuq. Kairo: Dâr al-Fikr.

Al-Syatibi. t.th. Al-Muwâfaqāt fi Ushûl alSyari'ah. Bairut: Dâr al-Fikr.

Bakri, Asafri Jaya. 1996. Konsep Maqâshid Syari'ah Menurut Al-Syatibi. Jakarta: PT. RajaGrafindo Persada.

Djazuli, HA. 1993. Ilmu Fiqih. Bandung: Orba Shakti.

Esack, Farid. 2000. Al-Quran Liberalisme dan Pluralisme: Membebaskan Yang Tertindas, terj. Watung A. Budiman. Bandung: Mizan.

Hanafi, Hassan. 1981. Ad-Din wa as-Saurah fi Misr 1956-1981. Cairo: Maktabah Madbuli.

Hanafi, Hassan. t.th. Dirâsât Islâmiyyah. Kairo: Maktabah Anjilu Misriyyah.

Mas'adi, Ghufran A. 1997. Pemikiran Fazlur Rahman tentang Metodologi Pembaruan Hukum Islam. Jakarta: Rajawali Press.

Muslehuddin, Muhammad. 1997. Filsafat Hukum Islam dan Pemikiran Orientalis, terj. Yudian W. Asmin. Yogyakarta: Tiara Wacana.

Nn. Lebih Dekat Mengenal Ilmu Nasakh dan Mansukh, lihat di http://www.bimbie.com/nasikh-dan-mansukh.htm di akses pada tanggal 19 Agustus 2014

Rachman, Budhy Munawar. (ed.). 1995. Kontekstualisasi Doktrin Islam dalam Sejarah. Jakarta: Paramadina.

Rauf Muhammad Amin, Dialektika ljtihad dan Realita Kajian Metodologis Aktualisasi Hukum Islam Kontemporer, lihat di http://saidnazulfiqar.wordpress.com/2005/04/02/dialektika-ijtihad-dan-realita/ diakses pada tanggal 15 Agustus 2014

S Samsidar, Signifikasi Maqâshid al-Syarî‘ah, lihat di download.portal-garuda.org-/article.php?...Syatibi\%20T... diakses pada tang-gal 19 Agustus 2014 
Supriyadi, Dedi. 2007. Sejarah Hukum Islam: Dari Kawasan Jazirah Arab sampai Indonesia. Bandung: Pustaka Setia.

Syaukani, Imam. 2006. Rekonstruksi Epistemologi Hukum Islam Indonesia. Jakarta: PT. RajaGrafindo Persada.
Tibi, Bassam. 1999. Islam Kebudayaan dan Perubahan Sosial, terj. Misbah ZE dan Zainul Abbas. Yogyakarta: Tiara Wacana.

Tim Penyusun Kamus P3B. 1995. Kamus Besar Bahasa Indonesia. Jakarta: Balai Pustaka. 